\title{
HELPING AFGHANISTAN'S INFORMAL DISPUTE RESOLUTION SYSTEMS FOLLOW AFGHAN LAW IN CRIMINAL MATTERS: WHAT AFGHANISTAN CAN LEARN FROM NATIVE AMERICAN PEACEMAKING PROGRAM
}

\author{
Ghazi Hashimi
}

Informal dispute resolution is common in rural areas of Afghanistan because of a general lack of access to or inefficiency of the formal mechanisms in those areas. While the Afghan informal dispute resolution systems have been known to resolve some criminal cases in ways that violate human rights or deviate sharply from Afghan formal law, it is possible to minimize these practices while taking advantage of some of the strengths that informal dispute resolution offers. This paper argues that some Native American Tribal justice systems could serve as helpful models for the Afghan approach to informal justice because they offer effective informal dispute resolution and peacemaking systems that are consistent with the formal justice system and do not violate human rights. Accordingly, this paper begins with an introduction to informal dispute resolution mechanisms in both Afghanistan and selected Native American Tribal systems, elaborating on the interaction between the informal and official state laws in these various systems. Next, it describes the failed attempts of the Afghan central authority to rule in the informal justice systems and integrate them into the formal legal structure. Then the paper will provide possible solutions which would include coordination between the formal and informal justice systems, monitoring of the cases within the informal system, including important criminal cases such as honor killings, theft, rape, and serious injury by members of the official system including provincial governor, district governor, and other law enforcement institutions. Finally, this paper offers some suggestions for how to respond once the monitoring bodies identify violations of human rights and Afghan law. 
I. INTRODUCTION TO AFGHAN INFORMAL DISPUTE RESOLUTION ............. 79

II. An Introduction to the Afghan Legal System ..................................... 82

III. BACKGROUND: PROBLEMS OF INFORMAL DISPUTE RESOLUTION IN

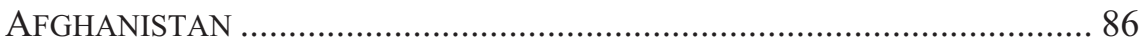

a. Peaceful Informal Dispute Resolution...................................... 87

b. Informal Dispute Resolution and Violations of Individual Rights 89

c. Government Efforts in the Past Decade......................................... 92

IV. FORMAL CRIMINAL JUSTICE SYSTEM IN AFGHANISTAN .........................99 94

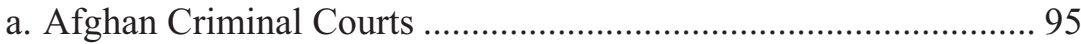

b. Jurisdiction of Criminal Courts ...................................................... 95

V. INFORMAL CRIMINAL JUSTICE SYSTEM …............................................ 96

a. Traditional Mechanisms of Dispute Resolution ............................ 97

b. Benefits and Drawbacks of Traditional Mechanisms of Dispute

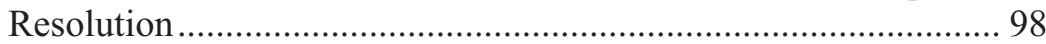

VI. AN INTRODUCTION TO THE NATIVE AMERICAN LEGAL SYSTEM ....... 100

VII. FORMAL NATIVE AMERICAN JUSTICE SYSTEM ................................. 101

a. Native American Courts ......................................................... 102

b. Jurisdiction of Native American Tribal Courts over Criminal

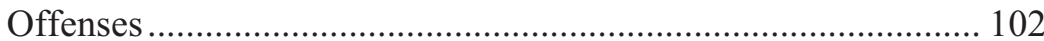

VIII. NATIVE AMERICAN INFORMAL CRIMINAL JUSTICE SYSTEM ............ 104

a. Traditional Dispute Resolution.................................................. 104

b. Peacemaking \& Peacemakers ................................................. 106

i. Peacemaking in Criminal Cases ......................................... 109

ii. Peacemaking in Civil Cases.............................................. 110

IX. ANALYSIS: LESSONS FOR AFGHANISTAN FROM THE NAVAJO NATION110

a. Barriers to Implementing this New Approach .............................. 112

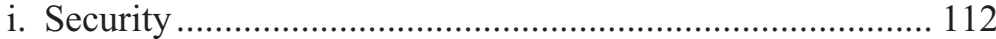

ii. Lack of Rule of Law .......................................................... 113

b. Suggestions for a New Approach to Working with the Informal Justice System.

i. Collaboration of Formal Courts and Law Enforcement Institutions with the Informal Justice System..................... 114

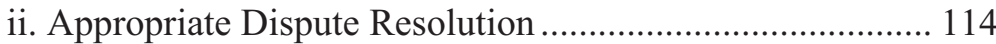

iii. Who Should Decide What? ................................................. 114

iv. Educating Community Members ...................................... 115

v. Communication, Monitoring, and Removal ....................... 115 
I. INTRODUCTION TO AFGHAN INFORMAL DISPUTE RESOLUTION

Afghan informal dispute resolution is a procedure in which parties bring their cases to community leaders or a third party who assists discussions and negotiations to reach a solution and to avoid legal proceedings. ${ }^{1}$ Informal dispute resolution is common in rural areas of Afghanistan because of a general lack of access or inefficiency of the formal mechanism in those areas. ${ }^{2}$ The Afghanistan Independence Human Right Commission illustrates in their report that there are no trial courts in 86 districts, "176 districts have no detention center and 92 districts have no active attorney." ${ }^{33}$ Hence, a large number of criminal and civil disputes in Afghanistan are decided outside of the formal legal system through shuras and jirgas-informal systems that apply customary law. ${ }^{4}$

The Afghan informal dispute resolution system has been praised for its advantages such as promptness, clarity, cultural familiarity, reliable and prompt resolutions, low cost, and accessibility. ${ }^{5}$ It also has a reputation for unanimous enforceable decisions, trustworthiness and fairness, restorative justice, and preservation of harmony within the community. ${ }^{6}$ Accordingly, a wide variety of civil and criminal disputes are resolved at the community level — most of which are land, water, and fuel disputes in civil cases, and deliberate and accidental killings, theft, runaways, and rape in criminal cases. ${ }^{7}$

1. NoAh Coburn \& John Dempsey, U.S. Inst. of Peace, Information Dispute $\begin{array}{llll}\text { RESOLUTION IN AFGHANISTAN } & 3 & \text { (2010), }\end{array}$ http://www.usip.org/sites/default/files/resources/sr247_0.pdf.

2. Thomas Barfield et al., U.S. Inst. of Peace, The Clash of Two Goods: State And Non-State Dispute Resolution in Afghanistan 2 (2006), http://www.usip.org/files/file/clash_two_goods.pdf.

3. President's Judicial Strengthening Decree Had No Impact: AIHRC, TOLO NEWS (Mar. 3, 2013, 9:12 AM), http:/www.tolonews.com/afghanistan/presidentsjudicial-strengthening-decree-had-no-impact-aihrc.

4. John Dempsey \& Noah Coburn, U.S. Inst. of Peace, Traditional Dispute RESOLUTION AND STABILITY IN AFGHANISTAN 2 (2010), https://www.usip.org/sites/default/files/PB\%2010\%20Traditional\%20Dispute\%20Resolut ion $\% 20$ and $\% 20$ Stability $\% 20$ in $\% 20$ Afghanistan.pdf.

5. Id. at 3 .

6. Id.; see also BARFIELD ET AL., supra note 2.

7. Deborah J. Smith, Keeping the Peace; Gender, Justice and Authority: Mechanisms for Community Based Dispute Resolution in Afghanistan, in BEYOND THE 
While informal dispute resolution serves a respected and important role in Afghanistan, some of the common practices have been criticized for violating human rights and sharply deviating from Afghan formal laws. ${ }^{8}$ For example, women are completely excluded in the judgment processes - men represent women and women are not allowed to defend themselves or to be present during any hearings or proceedings. ${ }^{9}$ Another criticism of the Afghan informal dispute resolution system is that community-based mechanisms can be very susceptible to influence by warlords. ${ }^{10}$ These local power-holders, who are sometimes elected as members of informal dispute resolution councils, are more likely to misuse the informal system. ${ }^{11}$ Finally, other important concerns include customary practices like honor-killings, forced and underage marriage, badal (or direct vengeance), and payment of blood money in lieu of punishment. ${ }^{12}$ One of the most controversial practices in the informal system is the practice of "baad"- the forced marriage of a woman from an offender's family to the victim's close relative to settle a dispute. ${ }^{13}$ This aspect of informal dispute resolution has caught serious attention of the international community and human rights activists. ${ }^{14}$ In fact, the Afghan government has been under extreme pressure to resolve this issue by trying to establish a relationship with informal justice mechanisms. ${ }^{15}$

This paper attempts to show how those government efforts could be improved for more effective use of resources and increased justice for the Afghan people through learning from the example of Native American tribes. Native American Tribal justice systems could serve as

'Wild Tribes': Understanding Modern Afghanistan And Diaspora 75 (Ceri Oeppen \& Angela Schlenkhoff eds., 2010).

8. BARFIELD ET AL., supra note 2, at 3.

9. Id.; see generally U.S. InSt. OF PEACE, CONFERENCE ON THE RELATIONSHIP Between State And Non-State Justice Systems in Afghanistan (2006), http://www.usip.org/sites/default/files/file/conference_summary_paper.pdf.

10. See BARFIELD ET AL., supra note 2, at 14-15; see also U.S. AgENCY FOR INT'L Dev., Afghanistan Rule of Law Project: Field Study of Informal and Customary Justice In AFGHANiSTAN AND RECOMMENDATIONS ON IMPROVING ACCESS TO JUSTICE AND RELATIONS BETWEEN Formal COURTS AND INFORMAL BODIES 11 (2005).

11. United States AgenCy For InTERNATIONAL DEVELOPMENT, supra note 10.

12. BARFIELD ET AL., supra note 2, at 3.

13. United States Institute of PeAce, supra note 9, at 3.

14. BARFIELD ET AL., supra note 2, at 3.

15. Id. at 24 . 
helpful models for the Afghan approach to informal justice because they offer effective informal dispute resolution and "Peacemaking" systems that follow rules and regulations set by the formal tribal justice system. For instance, some Native American tribes use Peacemaking Programs for family disputes, alcohol related behavior, domestic violence, and even sex offenses. ${ }^{16}$ Through the Peacemaking system, Peacemakers do not make decisions or impose punishments; however, they facilitate and guide parties to talk and to discuss the causes of conflict so that they can reach a decision amongst themselves. ${ }^{17}$ Peacemakers encourage parties to eliminate conflicts by opening communication with respect and responsibility, helping parties assist themselves through healing their spirits, minds, and bodies. ${ }^{18}$ Peacemakers work in cooperation and harmony with the formal justice system. ${ }^{19}$ Learning from this cooperative approach in which traditional ways of dispute resolution are respected, this paper argues that, similar to the Native American informal justice system, the formal justice system in Afghanistan should form a relationship of communication and respect with the informal systems. This relationship could enable a process of monitoring by the formal system and an acceptable procedure by which formal courts could take jurisdiction over serious crimes such as honor killings, murder, rape, and sex offenses.

This paper begins with an introduction to informal dispute resolution mechanisms in both Afghanistan and selected Native American Tribal systems, elaborating on the interaction between the informal and official state law in these various systems. Next, it describes the failed attempts of the Afghan central authority to rule in the informal justice systems and integrate them into the formal legal structure. Then the paper will provide possible cooperative solutions which would include coordination and respect between the formal and informal justice systems, monitoring of cases by members of the formal system including provincial governor, district governor, and other law enforcement institutions, and implementing procedures for removing important criminal cases such as

16. See generally Judicial Branch of the Navajo Nation, Peacemaking (A Guide to the Peacemaking Program of the Navajo Nation) (2004), http://www.navajocourts.org/Peacemaking/peaceguide.pdf.

17. Id.

18. Id.

19. See generally id. 
honor killings, theft, rape, and serious injuries to the formal system. Finally, this paper offers some suggestions for how to respond once the monitoring bodies identify violations of human rights and formal Afghan law.

\section{An Introduction to the Afghan Legal System}

The complexities of Afghanistan's geography and religious, cultural, and political history have led to an equally complex legal landscape that incorporates various cultural traditions and religious perspectives. ${ }^{20}$ As a landlocked country located in central Asia, its culture, traditions, and customs reflect those of its neighbors such as Pakistan, Iran, Turkmenistan, Tajikistan, Uzbekistan, and China. ${ }^{21}$ Afghanistan has been an essential strategic and geopolitics location throughout its history. Islam was brought to Afghanistan during the eighth century by the followers of Prophet Muhammad (PBUH). ${ }^{22}$ Prior to the introduction of Islam, Afghanistan was ruled by various Persian, Greek, Sassasian, and Central Asian empires. ${ }^{23}$ In 1747, Ahmad Shah was elected by an Afghan Jirga as king of Afghanistan. ${ }^{24} \mathrm{He}$ unified different Afghan tribes and extended its emperor ${ }^{25}$ His clan was able to rule Afghanistan for the next 200 years. $^{26}$ Contemporary Afghanistan has a population of approximately $30,000,000$ and its legal system is composed of three competing parts: Islamic law, customary law, and civil law. ${ }^{27}$ This mixture of Islamic, customary law, and civil law somewhat overlap. ${ }^{28}$

20. Adam Ritscher, A Brief History of Afghanistan, Address at the Students Against War Teach-In (2002), http://www.afghangovernment.com/briefhistory.htm.

21. See generally Marvin G. Weinbaum, U.S. Inst. Of Peace, Afghanistan AND ITS NeIghbors: An Ever DANGERous NeIghborhood (2006).

22. Ritscher, supra note 20.

23. William Kerr Fraser Tytler, Afghanistan: A Study of Political DEVELOPMENT IN CENTRAL ASIA 47 (1950).

24. Jaswant Lal Mehta, Advanced Study in the History of Modern India, $1707-1813$ at $246-48(2005)$.

25. Ritscher, supra note 20.

26. Id.

27. Afg. Research and Evaluation Unit, The A to Z Guide to Afghanistan Assistance 75 (Jay Lamey ed., 9th ed. 2011); see also MARTIN LAU, INT'L COMM'N OF JuRISTS, AFGHANISTAN's LEgAL SYSTEM AND ITS COMPATIBILITY WITH INTERNATIONAL HUMAN RigHTS STANDARDS 4 (2002).

28. BARFIELD ET AL., supra note 2, at 22. 
Throughout its history, Afghanistan's legal system was based on Islamic law and customary law. ${ }^{29}$ Islamic law was implemented by proficient religious judges following the Hanafi jurisprudence. ${ }^{30}$ Unlike common law, there was no system of judicial precedent (stare decisis) in the country. ${ }^{31}$ Islamic scholars (Ulama) were supposed to use their broad knowledge of Islamic law and its authoritative sources, Quran, hadith, and Hanafi jurisprudence to create legal norms. ${ }^{32}$ Until the formation of the modern Afghan state, Islamic scholars were independent in leading the legal system and providing both laws and legal interpretations. ${ }^{33}$ In other words, the Afghan legal system fell under religious law. Customary law was implemented in the most rural areas; at the same time, however, there were no statutory provisions. ${ }^{34}$

There are variations from province to province with respect to the relationships between formal and informal justice systems - meaning that in some provinces, people refer to informal justice systems more than they do to formal justice systems. ${ }^{35}$ In some provinces such as Nangarhar, there is collaboration between the formal and informal justice systems ${ }^{36}$ However, in some other provinces, the courts are averse to the informal dispute resolution system. ${ }^{37}$ Legal pluralism in Afghanistan is composed of the interaction and cooperation between Sharia law, custom, and state law including international human right principles within the state law's framework. ${ }^{38}$ Accordingly, the key features of legal

29. Id. at 12-13; see also Amin TARzi, U.S. Inst. of PeAce, Historical Relationship Between State and Non-State Judicial Sectors in Afghanistan 2 (2006).

30. BARfield ET AL., supra note 2, at 12; see also Amin Tarzi, The Judicial State: Evolution and Centralization of the Courts in Afghanistan, 1883-1896 (May 2003) (unpublished Ph.D. dissertation, New York University).

31. See Thomas Barfield, Afghan Customary Law and Its Relationship to

Formal Judicial Institutions, U.S. Inst. OF PEACE 2 (2003), http://www.usip.org/files/file/barfield2.pdf.

32. BARFIELD ET AL., supra note 2, at 12.

33. BARFIELD, supra note 31 , at 2 .

34. See generally id.

35. United States Institute OF Peace, supra note 9, at 2.

36. Smith, supra note 7, at 77-80.

37. Esther Meininghaus, Legal Pluralism in Afghanistan, in WORKING PAPER Series 72, at 16 (Amu Darya Project Working Paper No. 8, 2007).

38. Id. at 1 . 
pluralism defined in Afghanistan's context constitute religious, customary law, and statutory law. ${ }^{39}$

In the late $20^{\text {th }}$ century, the codification process began and state legal codes became the exclusive source of legal authority - these laws were firmly based on Islamic Law. ${ }^{40}$ King Abdur Rahman began to codify statues and codes in $1880 .{ }^{41}$ He created a state-run court system and elevated the status of Islamic law to the status of official state law. ${ }^{42}$ Through legal reforms, he distinguished sources of law in Afghanistan. ${ }^{43}$ He divided them into three categories: Islamic law, customary law, and statutory law. ${ }^{44} \mathrm{He}$ also established three types of courts: Islamic law courts, criminal courts, and commercial law courts. ${ }^{45}$ Thus, the legal system of Afghanistan became mixed. In 1923, during King Amanullah's reign, the first modern constitution of Afghanistan was passed and major social and legal reforms were carried out through a series of codes and decrees. ${ }^{46}$ Turkish and French advisers assisted with these legal reforms. ${ }^{47}$ Thus, it was the French civil law that made the basis of much of King Amanullah's legislation. ${ }^{48}$ Since then, hundreds of laws have been passed throughout different regimes. ${ }^{49}$

39. Naafay Choudhury, Reconceptualizing Legal Pluralism in Afghanistan, in The Selected Proceedings of the $3^{\text {RD }}$ Annual Canadian Law Student Conference, Windsor ReV. of Legal And Soc. Issues 21, 36-37 (S. Alex Constantin et al., eds., 2010); Thomas Barfield, Culture and Custom in Nation-Building: Law in Afghanistan, 60 ME. L. REV. 347, 351 (2008).

40. Meininghaus, supra note 37; Katherine McCullough, Out with the Old and in with the New: The Long Struggle for Judicial Reform in Afghanistan, 19 Geo. J. LEGAL ETHICS 821, 824-25 (2006).

41. Ramin Moschtaghi, Afghan Court Organization and its Compliance With the CONSTitution AND InTERnATIONAL LAW 3 (Max Planck, 3rd ed. 2009).

42. See generally Tarzi, supra note 30 .

43. Id.

44. Tarzi, supra note 29 , at 3-4.

45. MoschTAGHI, supra note 41 , at 4 .

46. See generally LeOn B. Poullada, Reform and Rebellion in AfGHANistan, 1919-1929: King Amanullah's Failure to Modernize a Tribal Society (Cornell University Press 1973).

47. MoschtaGHI, supra note 41, at 3.

48. Id. at 5 .

49. For most of these laws, see generally MOHAMMAD HASHIM KAMALI, LAW IN Afghanistan: A STUdy of CONSTITUtions, Matrimonial LAW AND the Judiciary (C. A. O. van Nieuwenhuijze ed., 1985). 
Adopted in 2004, the new Constitution of Afghanistan identified the Supreme Court as the highest judicial organ, heading the judicial power of Afghanistan. ${ }^{50}$ Until 2005, the 1990 Law of the Jurisdiction and Organization of the Courts of Afghanistan governed the court system. ${ }^{51}$ In June 2005, the Afghan government passed a new law regulating the judiciary and courts - Law on Organization and Authority of the Courts of Afghanistan. ${ }^{52}$ According to the new law, the court hierarchy in Afghanistan is comprised of the Supreme Court as the highest court and final court of appeal, the Appellate Court as the intermediate court, and the Primary Court. ${ }^{53}$ The new law also provided for the establishment of special courts such as family courts and an anti-corruption court. ${ }^{54}$

Custom forms a core foundation of the Afghanistan's legal system. Many Afghan people see themselves as good Muslims, so they believe their culture and customs should be in accordance with Islamic Laws. ${ }^{55}$ Researchers Sharma and Kumar state in an article that customary law in Afghanistan is a combination of the historical, traditional, and local understanding of Shari'a and sometimes the spiritual interpretation of Sufi preachers. ${ }^{56}$ Furthermore, Ali Wardak in his seminal article, "Building a Post-War Justice System in Afghanistan," notes that customary law resembles the spirit of "restorative justice," where values are put on the restoration of dignity and friendship between offenders

50. The Constitution of the Islamic Republic of Afghanistan Jan. 26, 2004, art. 116; Rep. of S.C., Agreement on Provisional Arrangement in Afghanistan Pending the Re-establishment of Permanent Government Institutions, U.N. Doc. S/2001/1154, at 4 (2001).

51. Matteo Tondini, State building and Justice Reform: Post-Conflict ReCONStruction in Afghanistan 52-53 (Michael Pugh ed., 4th ed. 2010).

52. Id.

53. See generally MinistRY OF JUSTICE, Law on Organization and Jurisdiction of Courts of the Islamic Republic of Afghanistan, 851 OfFICIAL GAZETTE 1 (2005).

54. The Constitution of the Islamic Republic of Afghanistan, arts. 69, 78, 127; TONDINI, supra note 51, at 52-53.

55. See generally T. Barfield, Afghanistan: The Local and the Global in the Practice of Shari'a, in SHARI'A POLITICS: ISLAMIC LAW AND SOCIETY IN THE MODERN WORLD 179 (Robert Hefner ed., 2011).

56. Sudhindra Sharma \& Pawan Kumar Sen, Institutionalization of the Justice System, in State Building, Security, and Social Change in Afghanistan: Reflections on a Survey on the Afghan People 46 (Ruth Rennie ed., 2008). 
and victims. ${ }^{57}$ William Maley, a researcher on Afghanistan's post-war justice reforms, also suggests that customary law gives traditional legitimacy to Afghanistan's legal system. ${ }^{58}$

Although some customs are essential to dispute resolution, some of them are harmful to society and conflict with state laws. For instance, jailing the women who run away from forced marriages without family permission; the practice of badal (the exchange of girls between two families); the marriage promise of an unborn girl to an unborn boy; engagement during childhood; and badd (where girls are given for marriage as compensation for a crime - the girls get married to a member of the family of the victim to end and prevent future enmity between the families). ${ }^{59}$ These traditional approaches to conflict resolution, restoration, and punishment are problematic, but widely practiced. However, there are also many important, just, and effective ways that the informal justice system helps people resolve conflict, addressing a wide range of issues including civil disputes such as land, family disputes, and criminal disputes such as, murder, theft, and assault, rape, and adultery. ${ }^{60}$

\section{BACKGROUND: PROBLEMS OF INFORMAL DISPUTE RESOLUTION IN AFGHANISTAN}

Throughout history, the Afghan formal legal system has tried to play a central role in governing of the lives of the majority of Afghan citizensespecially in rural areas. A split in the legal system between formal and informal has existed ever since an endeavor was made to create statutory laws. ${ }^{61}$ However, after the Taliban government fell, informal dispute resolution increasingly gained authority because the new government failed to control rural areas and to provide security to the public. ${ }^{62}$

57. Ali Wardak, Building a Post-War Justice System in Afghanistan, 41 CRIME, LAW \& SOC. CHANGE 319, 336 (2004).

58. William MaLey, ASia Foundation RePORT 2008, BUILDING LEGITIMACY IN Post-Taliban Afghanistan, State Building, Security and Social Change in Afghanistan: Reflections on a Survey of the Afghan People 7 (2008).

59. Meininghaus, supra note 37, at 13; United States Agency FOR INTERNATIONAL DEVELOPMENT, supra note 10, at 48.

60. See generally DEMPSEY \& COBURN, supra note 4.

61. Alison Luke et al., Customary Laws: Background, in WOMEN's EQUALITY IN AFGHANISTAN, http://www.iwrp.org/pdf/afghan_paper.pdf.

62. $I d$. 
Afghanistan has fourteen different ethnic groups who share a common religion: Islam. ${ }^{63}$ Their combination of cultures and strong religious beliefs create the regional informal justice system that is practiced in Afghanistan today. ${ }^{64}$ Some of the informal dispute mechanisms may violate human rights, ${ }^{65}$ while others are beneficial to the Afghan community. This paper will address both harmful and peaceful aspects of dispute resolution.

\section{a. Peaceful Informal Dispute Resolution}

Despite the serious problems discussed above, a majority of Afghans continue to turn to traditional or informal justice mechanisms to address both civil and criminal disputes. These mechanisms include tribal councils, consultation, and mediation with village and religious leaders. ${ }^{66}$ In rural areas of Afghanistan, including areas recently cleared of insurgents, the best mechanism to make essential, visible, short-term gains in peacefully resolving disputes is to refer cases to the local traditional mechanisms, "including tribal and community councils that have operated in local communities for centuries." "Th "These councils . . . [are usually composed] of community elders and other respected individuals sitting together to reach [reasonable] resolutions of disputes . . . ."68 In addition, informal dispute resolution has the advantage of familiarity with the people of communities in rural areas and is less costly, more accessible, and more effective than formal courts. ${ }^{69}$ The local shuras and jirgas focus on the consent of parties - not on a winner and loser - so a decision is reached faster than in formal courts. ${ }^{70}$ People in rural areas of Afghanistan have special respect for community

63. Id.

64. Id.

65. Kathryn Lockett, The Situation of Women and Girls in Afghanistan, in Beyond the 'Wild Tribes': Understanding Modern AFghanistan AND its Diaspora 34 (Ceri Oeppen \& Angela Schlenkhoff, eds., 2010).

66. DEMPSEY \& COBURN, supra note 4, at 2.

67. Id.

68. Id.

69. Id.

70. Id. 
leaders and elders; thus, because they are respected, most of leaders' decisions are accepted by parties to the dispute. ${ }^{71}$

For instance, in the Bamiyan province of Afghanistan, a girl whose name was Aqela loved a boy whose name was Nasir. ${ }^{72}$ They wanted marry each other and Nasir asked the girl's father to accept their engagement. ${ }^{73}$ Aqela's father did not reject the request, but he demanded a high bride-price from Nasir. ${ }^{74}$ Nasir could not afford this price so the couple ran away together. ${ }^{75}$ When elders of the village caught them, they investigated whether the girl ran away freely or by force. ${ }^{76}$ When they found that the girl had gone with Nasir freely, they advised the girl's family to agree on an affordable bride-price. ${ }^{77}$ Aqela's father finally accepted and the couple was able to marry each other. ${ }^{78}$ This case illustrates how elders can help communities solve their disputes in a peaceful ways, in less time, and with desirable results.

In another case, Jalasa (an elders' panel) endeavored to solve a family dispute between two brothers peacefully. ${ }^{79}$ The victim, Fauzia, was beaten by her brother-in-law's family which resulted in a miscarriage. ${ }^{80}$ After referring the case to Jalasa, the panel found Fauzia's brother-inlaw guilty and decided that he should compensate all of Fauzia's medical expenses. ${ }^{81}$ The parties agreed, and the dispute was resolved peacefully. 82

In addition to solving these smaller disputes between individuals, sometimes jirga and shura can solve much larger disputes too and in much less time than a formal Afghan court. ${ }^{83}$ An example of such a

71. COBURN \& DEMPSEY, supra note 1 , at 2-3.

72. See Deborah J. Smith \& Shelly Manalan, Community-Based Dispute Resolution Processes in BamiYan Province 44 (Vicki Quinlan ed., Afg. Research and Evaluation 2009).

73. Id.

74. Id.

75. See id.

76. Id.

77. Id.

78. Id.

79. See id. at 40.

80. Id.

81. Id.

82. See id.

83. DEMPSEY \& COBURN, supra note 4, at 3; see also Smith, supra note 7, at 7677. 
dispute concerned possession of and the right to live in a village as a member of a particular clan or tribe. ${ }^{84}$ Two qawms (clans), "(one of settled villagers and one of Kuchi, who had migrated to the area for generations, and who during the Soviet-mujahideen war had settled in the village more permanently)," in Nangarhar province had a land dispute that led a villager to burn Kuchis' houses. ${ }^{85}$ This large dispute was brought to various formal courts and government bodies since the collapse of the Soviet Union; however, the courts were unable to solve the dispute. ${ }^{86}$ However, recently, a jirga, presided over by the governor of the Nangarhar province, was capable of solving this dispute. ${ }^{87}$ Even though the government officials were involved, such as the governor and police, none of the violators who burned the houses were ever prosecuted. ${ }^{88}$ Instead of prosecuting them, the jirga used customary practices to maintain peace in the village ${ }^{89}$ According to the decision of the jirga, those who burned the houses had to apologize and walk toward the Kuchis' village without showing pride. ${ }^{90}$ In addition, the Kuchi had to commit themselves to the village and to protect the security of the village and its people from outside threats. ${ }^{91}$

The above decisions show not only fairness but also prevention of enmity between families and communities. For this reason, this paper asserts that the Afghan government, and also the people of the various Afghan communities, should support the continuation and preservation of this kind of informal dispute resolution.

b. Informal Dispute Resolution and Violations of Individual Rights

Although informal dispute resolution is more accessible, less costly, more legitimate, and less corrupt than government courts, it frequently fails to protect many basic individual rights, particularly women's rights.

84. See Smith, supra note 7, at 76-77.

85. Id. at 76.

86. Id.

87. Id.

88. Id.

89. Id. at 76-77.

90. Id. at 77 .

91. Id. 
In addition, informal dispute resolution sometimes violates state law and Islamic principles. ${ }^{92}$ Some examples of harmful informal dispute resolution outcomes are Baad (giving away girls to settle disputes, kidnaping or adultery), Baadal (exchange marriages), child marriages, and honor killings. ${ }^{93}$

The practice of baad (giving away of girls to resolve a dispute) is common in some rural areas of Afghanistan. ${ }^{94}$ According to a report of United Nations Assistance Mission in Afghanistan, in the central region of Afghanistan, where the government has less authority and weak institutions, baad is widely-practiced..$^{95} \mathrm{As}$ an informal dispute resolution, baad is used for resolution of criminal cases involving adultery, rape, and murder. ${ }^{96}$ The practice of baad contradicts state law, Islamic principles, and violates human rights. As an example, in one murder case in the Wazir tribe of Afghanistan, a jirga decided that the defendant family should give the murder victim's family 300,000 Pakistani Rupees as compensation; further, a girl was arranged to be married to a member of the victim's family. ${ }^{97}$ The reason for these practices of giving girls for marriage is to tie two families together through marriage and to change the "severe enmity into friendship;" "98 however, the consent of the girl is not considered nor the future the girl will face. In addition, unlike formal courts, the jirga "seek compensation for the wrong done and social reconciliation, not the punishment of the [wrongdoer]." ${ }^{.99}$

92. See generally CHris JoHnson eT AL., AfGHANistan's Political AND Constitutional Development (Overseas Dev. Inst. 2003), https://www.odi.org/sites/odi.org.uk/files/odi-assets/publications-opinion-files/5888.pdf; Rep. of the U.N. Assistance Mission in Afg., Harmful Traditional Practices and Implementation of the Law on Elimination of Violence Against Women in Afghanistan (Dec. 9 , https://unama.unmissions.org/sites/default/filesharmful_traditional_practices_english.pdf [hereinafter UNAMA].

93. See generally UNAMA, supra note 92.

94. Id.

95. Id. at 11.

96. Id.

97. Luke et al., supra note 61.

98. Id.

99. BARFIELD, supra note 31, at 14. 
In another case from 2010, a 19 year-old girl was married to a 13-year old boy when her brother ran away with the boy's sister. ${ }^{100}$ In this case, the runaway girl was fleeing her forced engagement with another boy. ${ }^{101}$ A local shura from the Paryan district of Panjsher province mediated the case and decided that the father of the boy with whom the girl had eloped should pay $\$ 11,600$ and give one of his daughters as compensation to the family of the girl's previous fiancée. ${ }^{102}$ The father of the boy who eloped had to sell his livestock and land to pay for this compensation. ${ }^{103}$

Another example of harmful informal dispute resolution outcomes is the forced marriage of adulterers and victims of kidnaping. "In cases involving the kidnapping of women or adultery, some tribes force the parties to marry, even against the wishes of the female involved." 104 "Marriage is often ordered in these cases on the basis of a belief that the female's chastity may have been taken, thereby compromising the honour and dignity of the woman and her family." "For example, in Nuristan [province of Afghanistan], if a married women [sic] is 'consensually kidnapped,' the Jirga compels the current husband to divorce the woman so she can be married to the kidnapper." 106 "The former husband would be further compensated with the return of the dowry he previously paid and receiving animals from the offender."107 Similarly, in some parts of the Kunduz Province, "if an unmarried couple commits adultery, the couple is ordered to be married and the family of the woman is compensated." 108

Another dispute that is decided by the elders of a tribe or community is rape. ${ }^{109}$ "Investigation and penalty in rape cases is largely unaddressed within Afghan systems of customary law."110 "Loss of virginity is perceived as ruinous to the prospects of women and girls and, as such, is

$\begin{array}{ll}\text { 100. } & \text { UNAMA, supra note } 92, \text { at } 13 . \\ \text { 101. } & \text { Id. } \\ \text { 102. } & \text { Id. } \\ \text { 103. } & \text { Id. } \\ \text { 104. } & \text { Luke et al., supra note } 61 . \\ 105 . & I d . \\ 106 . & I d . \\ 107 . & I d . \\ 108 . & I d . \\ 109 . & I d . \\ 110 . & I d .\end{array}$


hidden by the community whenever possible." 111 In the case of rape or sexual harassment, when a woman reports that she has been raped or sexually harassed, the responsible male may be killed. ${ }^{112}$ When people discover a case of rape, the sentence imposed is harsh. "In one example, in a case of rape amongst Hazaras, the Jirga ordered the woman to receive 60 lashes and the male perpetrator be stoned to death." 113 Thereafter, her husband divorced her; she became depressed and finally died. ${ }^{114}$

These decisions conflict with Islamic principles which mandate that marriage is based on the complete consent of a boy and a girl - whether she is a virgin, divorced or widowed. ${ }^{115}$ Similarly, these decisions are against state laws of Afghanistan. ${ }^{116}$ For instance, Article 517 of the penal code states, "[a] person who gives in marriage a widow, or a girl who is [eighteen] years or older, contrary to her will or consent, [he or she] shall be sentenced in view of the circumstances to short[-term] imprisonment." ${ }^{117}$ In addition, Article 70 of the Civil Code states that the minimum age for marriage should be sixteen for girls and eighteen for boys. ${ }^{118}$ Moreover, Article 23(2)(3) International Convention on Civil and Political Rights, of which Afghanistan is a party, emphasizes free and full consent of men and women in marriage. ${ }^{119}$

\section{c. Government Efforts in the Past Decade}

For the past ten years, the Afghan government and international community have worked to address some of these issues within the informal justice system, but there has been little cognizable progress or

111. Id.

112. BARFIELD, supra note 31 , at 17.

113. Luke et al., supra note 61.

114. Id.

115. BARFIELD ET AL., supra note 2, at 7-8.

116. Id.

117. Penal Code of Afghanistan, 347 Official GAZETTE 13, art. 517 (1976).

118. Civil Code of the Republic of Afghanistan (Civil Code), 353 OfFICIAL GAZETTE, art. 70 (1976).

119. International Covenant on Civil and Political Rights art. $23 \S \S 2-3$, Dec. 19, 1966, 999 U.N.T.S. 171. 
change. ${ }^{120}$ Instead, the majority of success has been with legal and justice reforms - primarily in the form of legislative reforms. ${ }^{121}$ With corruption and deteriorated security as the biggest challenges, rural areas almost inevitably refer to traditional institutions to resolve their disputes; nonetheless, the above example of dispute resolution in the Nangarhar province highlight the role and monitoring of the informal justice system by Afghan state actors. ${ }^{122}$ Arsala Jamal, the governor of the Khost province requested The Liaison Office to create the Commission on Conflict Mediation (CCM or "the Commission"). ${ }^{123}$ The Commission was created in 2006, consisting of six respected tribal elders; it provides an informal dispute resolution to local people out-of-court. ${ }^{124}$ In the first eighteen months, the Commission received thirty-one cases of which eighteen were solved, ten were in process, and three were submitted to formal courts. ${ }^{125}$ The main reasons for the Commission's success are its ability to offer arbitration services free of charge and its ability to solve disputes impartially. ${ }^{126}$

Afghanistan has progressed in moving towards the effective rule of law both in formal and informal legal systems, including the construction and rebuilding of justice infrastructures, capacity building trainings, drafting and passing of new laws, improving traditional justice mechanisms, and working closely with Community Based Dispute Resolution Mechanisms, which are at the center of these successes. ${ }^{127}$ However, the predominance of warlords in some rural areas, wide-spread corruption in official offices, and lack of security in most areas of Afghanistan have slowed reforms. ${ }^{128}$

120. William Maley, Building Legitimacy in Post-Taliban Afghanistan, in STATE Building, SECurity, AND Social Change in AFGHANistan, supra note 56, at 11.

121. See generally InT'L CRISIS GRP., REFORMING AFGHANISTAN'S BROKEN JUDICIARY (2010).

122. Smith, supra note 7, at 76-80.

123. See generally The Liaison Off., U.S. Inst. of Peace, Between the JiRGa AND THE JUDGE (2009), http://www.usip.org/files/file/jirga_judge.pdf.

124. Id.

125. Id.

126. Id.

127. SMITH \& MANALAN, supra note 72, at 41.

128. See generally NoAh Coburn, U.S. Inst. Of Peace, Informal Justice AND THE INTERNATIONAL COMMUNITY IN AFGHANISTAN (2013), https://www.usip.org/sites/default/files/PW84- 
Afghanistan is an Islamic country and according to the Constitution of Afghanistan, no law can be passed in contradiction with Islamic principles. ${ }^{129}$ The Quran is the most powerful source of criminal law, containing up to thirty verses regarding criminal law-most of which refer to substantive criminal law rather than criminal procedure. ${ }^{130}$ According Islamic law, Tazir Crimes are lifted to the discretion of rulers who are bound to the principles of Islam. ${ }^{131}$ Accordingly, the Islamic government has the authority to create, adapt, and transplant criminal laws unless they contradict Islamic principles. ${ }^{132}$

On the other hand, Sharia has historically played a significant role in Afghanistan's legal system. ${ }^{133}$ Trained religious judges follow the Hanafi legal tradition implemented by Islamic religious law (shari'a). ${ }^{134}$ "They were part of a larger class of professional clerics (ulema) who issued opinions (fetwa) on religious issues." "135 There is comprehensive scholarship examining the role of Shari'a in Afghanistan legal society and studies have shown that Afghanistan's legal system is rooted deeply in Islamic principles. ${ }^{136}$ For instance, the first article of the 1976 Afghan penal code states that Hodod, Qassas and Diat crimes are punished in accordance with the Islamic provisions of Hanafi jurisprudence. ${ }^{137}$ Accordingly, the criminal code in Afghanistan is based on Islamic principles and the legislature fills the gaps. ${ }^{138}$

Informal $\% 20$ Justice $\% 20$ and $\% 20$ the $\% 20$ International $\% 20$ Community $\% 20 \mathrm{in} \% 20$ Afghani stan.pdf.

129. The CONSTitution of THE Islamic RepubliC OF AfGHANiSTAN art. 3.

130. Silvia Tellenbach, Fair Trial Guarantees in Criminal Proceedings Under Islamic, Afghan Constitutional and International Law, 64 ZAÖRV 929, 929 (2004).

131. Id. at 930 .

132. Id.

133. See BARFIELD, supra note 31 , at 2 .

134. Tellenbach, supra note 130, at 932 .

135. Barfield, supra note 39, at 352; Wardak, supra note 57, at 324.

136. Tellenbach, supra note 130, at 932.

137. Ministry of Justice, Penal Code, 347 Official Gazette, art. 1 (1976).

138. Orzala Ashraf Nemat, Comparative Analysis of Family law in the CONTEXT OF ISLAM 5 (Jawed Nader trans., 2006); MinistRY OF ForeIGN AFFAIRS, ISLAMIC REPUBLIC OF AFGHANISTAN 1 (2007), http://mfa.gov.af/Content/files/ Romejointrecommandations.pdf. 
a. Afghan Criminal Courts

According to the Constitution of Afghanistan, the judiciary is an independent entity of the Islamic Republic of Afghanistan. ${ }^{139}$ It consists of the Supreme Court, appeal courts, and preliminary or trial courts that all consist of criminal courts. ${ }^{140}$ The Supreme Court manages its activities through its various departments or dewans. ${ }^{141}$ In addition, the Supreme Court is responsible for the administration of a court system consisting of 34 provincial courts and 384 primary courts throughout Afghanistan. ${ }^{142}$ The Supreme Court of Afghanistan has five divans-one of which is a criminal diwan. ${ }^{143}$ The second court with the highest authority is the Appellate court. ${ }^{144}$ All provinces have the Court of Appeals for various departments or diwans - one of which is a criminal diwan that settles criminal cases at the provincial level. ${ }^{145}$ The lowest court in the hierarchical structure of the Afghan court system is comprised of the primary courts. ${ }^{146}$ The primary courts are located within districts and cities. ${ }^{147}$ The numbers of departments vary from district and city. ${ }^{148}$ Generally, each district has a primary court that settles civil and criminal cases at the district level. ${ }^{149}$

\section{b. Jurisdiction of Criminal Courts}

The judiciary branch has exclusive authority to resolve disputes between individuals or institutions and individuals. ${ }^{150}$ According to Article 2 of Law on Organization and Jurisdiction of Courts, the

139. The Constitution of the Islamic Republic of Afghanistan art. 116.

140. Id.; see also MINISTRY OF JUSTICE, Law on Organization and Jurisdiction of Judiciary Branch of Islamic Republic of Afghanistan, 1109 OfFICIAL GAZETTE (2012).

141. MinistRY OF JUSTICE, supra note 140, art. 42.

142. The Constitution of the IsLAmic Republic of Afghanistan arts. 117-18, 121, 138; AFGHANISTAN RESEARCH AND EVALUATION Unit, supra note 27, at 77.

143. MinisTRY OF JUSTICE, supra note 140, art. 42.

144. Id. art. 52.

145. Afghanistan Research and Evaluation Unit, supra note 27, at 76.

146. See id.

147. Ministry of Justice, supra note 140, art. 61; see also AfGHANISTAN RESEARCH AND EVALUATION UNIT, supra note 27, at 76.

148. AFGHANISTAN RESEARCH AND EVALUATION UNIT, supra note 27, at 77.

149. See id. at 76.

150. MinistRY OF JUSTICE, supra note 140. 
judiciary is an independent body of the state: "The Judiciary shall be the independent pillar of the state and composed of the Supreme Court, Courts of Appeal and Primary Courts. Traveling courts may be established when needed, on recommendation by the Supreme Court and approval of the President." ${ }^{151}$ In addition, Article 4 of this law gives the courts exclusive jurisdiction to settle all cases within its personal and subject matter jurisdiction, "[n]o law under any circumstances may take a case out of the jurisdiction of judiciary and submit it to a different authority." 152 However, there is a huge gap between what is in the law and what is in action. ${ }^{153}$ In other words, in some areas, especially rural areas, the courts do not have jurisdiction and that is because of a lack of efficiency of formal courts in these areas. ${ }^{154}$

\title{
V. INFORMAL CRIMINAL JUSTICE SYSTEM
}

Because state justice organizations do not have much presence in many parts of the country, especially in rural areas, and are incapable of solving many disputes in justifiable ways that meet the needs of Afghanis, in many parts of the country, people prefer to bring their cases to informal dispute resolution mechanisms, or community-based dispute resolution, which they find to be more transparent, clear, and predictable. ${ }^{155}$ As explained in previous sections, these practices can involve such harsh remedies as forcing marriage between a girl from a murderer's family with a member of the murder-victim's family. ${ }^{156}$ Despite these deeply rooted traditions, Afghanistan's informal legal system is in flux ${ }^{157}$ because some educated people in rural areas do not want to follow informal dispute resolution that has negative effects on societies such as giving girls as compensation (Badal), child marriage, and so on. ${ }^{158}$

\author{
151. Id. art. 2 . \\ 152. Id. art. 4. \\ 153. TOLO NEWS, supra note 3. \\ 154. Id. \\ 155. DEMPSEY \& COBURN, supra note 4 , at 1 . \\ 156. UNAMA, supra note 92, at 11. \\ 157. See generally BARFIELD, supra note 31. \\ 158. Interviews with students, in rural areas of Afghanistan (Spring 2013).
}


a. Traditional Mechanisms of Dispute Resolution

Afghans have used traditional mechanisms of dispute resolution for centuries. $^{159}$ Informal mechanisms are known as jirgas, shuras, community development councils, and other Afghan customary justice mechanisms. ${ }^{160}$ The traditional mechanisms of dispute resolution pre-date the formal justice mechanisms and they have been used as a means of dispute resolution and communal reconciliation for issues of both a civil and criminal nature. ${ }^{161}$

The purpose of shura and jirga, or any other traditional mechanism of dispute resolution is to restore harmony in a community. ${ }^{162}$ Unlike formal courts, traditional dispute resolution bodies have a different objective. ${ }^{163}$ The formal courts focus on establishing guilt and punishing the guilty, while the traditional courts focus on the needs of the victim and society's harmony. ${ }^{164}$ To achieve this, Coburn Noah, a researcher and writer at the Unites States Institutes of peace points out that "[i]nformal dispute resolution often relies on bodies of elders whose collective reputations give the resolution legitimacy and create collective social pressure on the community to respect the decision." 165 The community elders and other respected individuals sit together in the shuras, jirgas, or other Community Development Councils to reach equitable resolutions and to reconcile the "disputants, their families and the community as a whole." 166 Traditional justice mechanisms are perceived by the local population to be less costly and more accessible than the state courts. ${ }^{167}$ Also, traditional justice resolution mechanisms are more likely to be enforced than those of state institutions because disregarding decisions of

159. See BARFIELD ET AL., supra note 2, at 2.

160. Id. at 7.

161. Smith, supra note 7, at 75 .

162. BARFIELD ET AL., supra note 2, at 7.

163. Id:: see also Idirs Iffat, Alternative Dispute Resolution: The Informal Justice Sector in Pakistan, in OCCASIONAL PAPER SERIES 3 (Lead Pakistan, 2007).

164. Iffat, supra note 163.

165. Noah Coburn, United States Institute of Peace Report 2011: The Politics of Dispute Resolution and Continued Instability in Afghanistan 4 (2011).

166. BARFIELD ET AL., supra note 2, at 6-7; DEMPSEY \& COBURN, supra note 4, at 2.

167. DEMPSEY \& COBURN, supra note 4 , at 2 . 
respected local leaders can be disruptive to social harmony. ${ }^{168}$ However, despite this effectiveness, judgments issued by local bodies have various problems: they are sometimes not recorded, they may favor the powerful, and they may occasionally discriminate against vulnerable groups, including women and children. ${ }^{169}$

b. Benefits and Drawbacks of Traditional Mechanisms of Dispute Resolution

Traditional mechanisms of dispute resolution have been praised for promptness, clarity, effectiveness, and being familiar to the population; they are also less costly and more accessible than formal courts. ${ }^{170}$ In addition, the decisions of shuras and jirgas tend to be acceptable for both sides of a conflict, reaching final resolutions in much less time than formal courts ${ }^{171}$ Unlike in court proceedings, the main purpose of informal resolution is to eliminate a dispute in a peaceful manner rather than focus on a winner and loser or on penalizing wrongdoers. ${ }^{172}$

Almost all of the literature on post-war justice systems in Afghanistan focus on the benefits of traditional mechanisms of dispute resolution, pointing to the effectiveness, cultural familiarity, lack of corruption, prompt resolutions, cheaper costs, accessibility, unanimity, enforceable decisions, trust and fairness, and focus on restorative justice and preserving harmony within the community. ${ }^{173}$ At the same time, traditional mechanisms of dispute resolutions are associated with sharp violations of state law and sometimes even Islamic principles, which reduces the appeal of traditional dispute resolution in the eyes of some people in Afghanistan and the international community. ${ }^{174}$

168. COBURN, supra note 165 , at 4 ; DEMPSEY \& COBURN, supra note 4 , at 2; Shahid M. Shahidullah, Comparative Criminal Justice Systems: Global and Local Perspectives 35 (Jones \& Bartlett Learning ed., 1st ed., 2012).

169. See generally UNAMA, supra note 92.

170. See Anne-Catherine Claude, Civil-Military Fusion Centre, Afghanistan - Justice and Reconciliation: The Informal Justice System in AFGHANISTAN 4 (2010).

171. DEMPSEY \& COBURN, supra note 4 , at 2.

172. Id.

173. Id. at 3 .

174. See generally UNAMA, supra note 92. 
Chief among these failings concerns the subjugation of women in the process itself. Traditional dispute mechanisms put men in a position of power and exclude women from the judgment processes; regardless of the nature of the dispute, whether it concerns rape, domestic violence, marriage, children, or property, men represent women and women are not allowed to participate in the proceedings or voice their own concerns. ${ }^{175}$

Second, the most criticized aspect of using traditional mechanisms of dispute resolution is baad - the marriage of a woman from the offender's family to the victim's close relative to settle a dispute. ${ }^{176}$ This aspect of the traditional dispute resolution has caught a lot of attention by the international community and human rights activists. ${ }^{177}$ Notably, the Afghan government has been under extreme pressure to resolve this issue by trying to establish a relationship with informal justice mechanisms in rural areas, but these efforts have mostly failed because law enforcement institutions are weak or do not exist at all in those areas. ${ }^{178}$

Third, community-based mechanisms can be very susceptible to dominance by warlords. ${ }^{179}$ Local power-holders, who are mostly elected as members of informal justice mechanisms through their influence and force, are more likely to misuse the informal system because they are driven to protect their own illegal activities and benefits - warlords use their gunmen and political influence to impose their decisions on both formal institutions and local people. ${ }^{180}$ In some instances, informal dispute resolution has become a shopping arena for rich people; in fact, they pay the warlords to judge in their favor when they have a dispute. ${ }^{181}$ Importantly, the poor have to accept any verdict either in their favor or not. ${ }^{182}$ Thus, involving warlords in settling criminal and civil disputes in

175. Luke et al., supra note 61, at 2.

176. UNAMA, supra note 92.

177. See generally UNAMA, supra note 92.

178. See generally BARFIELD, supra note 31.

179. See BARFIELD ET AL., supra note 2, at 14-15.

180. Heading for Trouble in Afghanistan, Michelsen InST. (Sept. 26, 2012), http://www.cmi.no/news/?1065-heading-for-trouble-in-afghanistan; see also Christina Pauly-Jones \& Neamat Nojumi, Balancing Relations Between Society and State: Legal Steps Toward National Reconciliation and Reconstruction of Afghanistan, 52 AM. J. COMP. L. 825, 825 (2004).

181. See generally BARFIELD, supra note 31 .

182. Id. 
the rural areas, where government institutions are weak and people are under influence of warlords, is a problem that has no easy solution. ${ }^{183}$ This issue impairs the reliability of informal dispute resolution. ${ }^{184}$ Finally, as few incidents have been illustrated in previous sections, other drawbacks include honor-killings, forced and underage marriage, and payment of blood money in lieu of punishment. ${ }^{185}$

In conclusion, with the majority of the Afghan population living in rural areas, the traditional mechanisms of dispute resolution will always be the first choice to resolve disputes, and with insufficient or no control by the government to monitor their process of judgment, the human rights violations threatens to remain a strong drawback and challenge to the justice system in Afghanistan. ${ }^{186}$ Therefore, the focus of next chapter will be on how to establish a relationship between the formal and informal justice systems to fight and eliminate these challenges.

\section{AN INTRODUCTION TO THE NATIVE AMERICAN LEGAL SySTEM}

Similar to Afghanistan, U.S. Native American tribes have grappled with balancing their formal justice systems with a long history of informal, traditional ways of resolving conflict. ${ }^{187}$ Traditionally, Native American tribes had various expressive and creative ways of conducting dispute resolution. ${ }^{188}$ These dispute resolution methods were not familiar to the European settlers. ${ }^{189}$ Thus, settlers discounted and even discouraged Native American methods of dispute resolution. ${ }^{190}$ In 1883, the Department of Interior established "Courts of Indian Offenses" or "Courts of Federal Regulations" ("CFR Courts") to settle less serious

183. See BARFIELD ET AL., supra note 2, at 14-15.

184. See id. at 16-17.

185. Ali Wardak, Daub Saba \& Halima Kazem, Afghanistan Human DEVELOPMENT REPORT 2007: BRIDGING MODERNITY AND TRADITION: RULE OF LAW AND THE SEARCH FOR JUSTICE 93 (2007), http://hdr.undp.org/sites/default/files/nhdr2007.pdf; see also BARFIELD ET AL., supra note 2, at 3.

186. COBURN \& DEMPSEY, supra note 1 , at 1.

187. Tribal Courts, Tribal COURT Clearinghouse, http://www.tribalinstitute.org/lists/justice.htm (last visited May 24, 2013).

188. See id.

189. Id.

190. Id. 
criminal cases among the tribal members. ${ }^{191}$ Many judges of these courts were non-Native American. ${ }^{192}$ In 1934, the Indian Reorganization Act (25 U.S.C.A. § 461, et. seq.) was adopted not only to allow Native American tribes to exercise their inherent sovereignty, but to establish their own justice codes, run their own court systems applying those laws, and create and adopt their own constitutions. ${ }^{193}$ Furthermore, the Act provided a framework for the tribes to gradually build and expand their tribal governments. ${ }^{194}$

Some tribes have been successful in developing judicial systems while others are trying to construct and develop their government within the U.S. adversarial system framework. ${ }^{195}$ Some tribes use and prefer the U.S. adversarial system, while others still apply traditional dispute resolution. ${ }^{196}$ Native American governments adopting new laws and their courts apply these laws along with custom and tradition to settle disputes. ${ }^{197}$ Thus, some Native American tribes use positive law, regulations, and traditions to settle civil and criminal disputes of their members. ${ }^{198}$

\section{Formal NATIVE AMERICAN JUSTICE SySTEM}

The Native American criminal justice systems are composed of both formal and informal methods of dispute resolution. ${ }^{199}$ In the Navajo reservation; there is a significant integration between formal courts and informal peacemaking courts through active monitoring and partnership. ${ }^{200}$ In addition, the Native American criminal justice system

191. Id.

192. Id.

193. Id.

194. Id.

195. See Raymond D Austin, Navajo Courts and navajo Common Law: A Tradition of Tribal Self-Governance 32 (2009).

196. Tribal Court Clearinghouse, supra note 187.

197. Id.

198. Id.

199. See generally Jeffrey Ian Ross \& Larry Gould, Native American Criminal Justice, Criminological Theory, and Policy Development, in NATIVE AMERICANS AND THE CRiminal Justice System (Jeffrey Ian Ross \& Larry Gould, eds., 2006).

200. Interview with Elaine Henderson, Peacemaker, in Navajo Nation, in Arizona (May 23, 2013). 
has a complex relationship with the U.S. state and federal systems that can result in conflicts and misinterpretation. ${ }^{201}$ The study of criminal justice systems in Native American reservations is complex and overloaded with "cultural, economic, emotional, political, and social undertones." 202

\section{a. Native American Courts}

The Native American formal tribal courts primarily rely on an adversarial system of dispute resolution similar to the U.S. state and federal courts. ${ }^{203}$ However, many contemporary tribal communities have adopted a dual justice system incorporating both the American model of justice and indigenous models of justice. ${ }^{204}$ The U.S. adversarial system includes pleadings, counterclaims, cross examination, discovery, and a final judgement, ${ }^{205}$ in contrast, under indigenous models of justice, community members and traditional methods of justice apply a more holistic philosophy guided by customary law, traditions, and practices that are learned primarily by example and through the oral teachings of tribal elders. ${ }^{206}$ Thus, the informal or traditional dispute mechanism in Native American tribes is based on a non-adversarial system. ${ }^{207}$

\section{b. Jurisdiction of Native American Tribal Courts over Criminal Offenses}

The jurisdiction of Native American courts over criminal offenses is restricted to the classification of the offense and the place of the

201. See generally Justin B. Richland, InTROduction to Tribal Legal Studies (2d ed. 2010).

202. Ross \& Gould, supra note 199, at 3, 4.

203. See generally Peacemaking Program of the Judicial Branch of the Navajo Nation, Plan of Operations (2013) [hereinafter Peacemaking], http://www.navajocourts.org/Peacemaking/Plan/PPPO2013-2-25.pdf.

204. See generally RICHLAND, supra note 201.

205. Judicial BRANCH OF THE NAVAJO NATION, supra note 16, at 4.

206. See William C. Bradford, Reclaiming Indigenous Legal Autonomy on the Path to Peaceful Coexistence: The Theory, Practice, and Limitations of Tribal Peacemaking in Indian Dispute Resolution, 76 N.D. L. REV. 551, 578-80 (2000).

207. See Matthew L.M. Fletcher, American Indian Tribal LaW 126 (2011). 
incident. $^{208}$ Offenders of serious crimes are tried in federal courts whereas crimes committed outside the reservation are within the state court's jurisdiction. ${ }^{209}$ Subject matter jurisdiction in criminal cases is related to the three following issues: 1) whether the victim and defendant are Indian, 2) whether the criminal act is committed in Indian country or on a reservation, 3) the nature of the crime or offense (whether it is felony or misdemeanor). ${ }^{210}$ According to the Major Crimes Act (18 U.S.C. $§ 1153$ (1988)), the federal government exercises its jurisdiction over Native American members if they commit one or more of the thirteen violent felonies that are listed as follows:"211 "Murder, manslaughter, kidnapping, maiming, a felony under chapter 109 A, incest, assault with intent to commit murder, assault with a dangerous weapon, assault resulting in serious bodily injury, arson, burglary, robbery and felony under section 661 of this title within Indian Country." 212 The Assimilative Crimes Act (18 U.S.C. $§ 1162$ ) and the Organized Crime Control Act are also applicable to members of Indian Country. ${ }^{213}$ Thus, tribal law enforcement institutions cannot settle the aforementioned criminal cases and the involvement of federal law enforcement agencies is necessary. ${ }^{214}$

However, approximately 170 reservations have their own law enforcement department, but they do not have exclusive jurisdiction on all criminal matters. ${ }^{215}$ First, they should distinguish the type of offense (felony or misdemeanor), offender (enroll member or state citizen), and place of crime (Indian country, state, or federal territory). ${ }^{216}$ Then, if the

208. See Eileen Luna-Firebaugh and Samuel Walker, Law Enforcement and the American Indian: Challenges and Obstacles to Effective Law Enforcement, in NATIVE Americans AND the CRiminal Justice System 117, 120 (Jeffrey Ian Ross \& Larry Gould, eds., 2006).

209. Marianne O. Nielsen, Navajo Nation Courts, Peacemaking and Restorative Justice Issues, 44 J. Legal PluRalism \& UnOfFicial L. 105, 109 (1999).

210. Luna-Firebaugh \& Walker, supra note 208, at 120.

211. Id. (citing 18 U.S.C. $§ 1153$ (1988)).

212. Id. at 133 n.4 (quoting. $§ 1153$ (1988)).

213. Id. at 120 .

214. See id. at 133-34.

215. Id. at 121.

216. Id. at 120. 
case meets the aforementioned three criteria, they can exercise their jurisdiction. ${ }^{217}$

\section{NATIVE AMERICAN INFORMAL CRIMINAL JUSTICE SYSTEM}

Many Native American tribes tend to have alternative dispute resolution mechanisms rooted in custom and traditional practices. ${ }^{218}$ One of the most effective and developed of these practices is "peacemaking" and "traditional dispute resolution." ${ }^{219}$ Traditional dispute resolution is an ancient form of dispute resolution in which people bring their cases to the elders who use custom and tradition to solve cases, while peacemaking is a mechanism that was created just a few decades ago through the help of formal courts and institutions in which a peacemaker brings parties together to discuss the conflict or dispute to reach a consensual agreement. ${ }^{220}$ Nowadays, both peacemaking and traditional dispute resolution are used to solve civil and criminal cases through informal mechanisms in Native American reservations. ${ }^{221}$

\section{a. Traditional Dispute Resolution}

Another type of dispute resolution is traditional dispute resolution in which tribal members use customary and traditional procedural norms that call for non-adversarial forms of conflict management. ${ }^{222}$ Although Indian tribes were given the authority to run their own court systems a century ago, some of them preferred to maintain traditional values of dispute resolution to a greater extent over formal courts. ${ }^{223}$ Thus, tribal courts have been using traditional law in different areas of law. ${ }^{224}$ The method of using traditional law varies from tribe to tribe; however, they

217. Id.

218. Carrie E. Garrow \& Sarah Deer, Tribal Criminal Law and Procedure 9 (1st ed., 2004).

219. See id. at 57-59.

220. See Judicial Branch of the Navajo Nation, supra note 16, at 1-2.

221. Interview with Elaine Henderson, supra note 200.

222. See Marilyn Holly, Navajo Criminal Justice: A Jungian Perspective, in Native Americans and the Criminal Justice System 17, 17 (Jeffrey Ian Ross \& Larry Gould, eds., 2006).

223. Id.

224. GARROW \& DEER, supra note 218 , at 58. 
all share a similar purpose reflective of native customs and traditions. ${ }^{225}$ The Navajo Nation has a "horizontal" traditional model of justice that is to show equality among people and, according to which, no person is above another. ${ }^{226}$ In this system, victims, defendants, and others who are effected by the committed crime, get together to discuss the situation, find the causes of crime, express their emotions, and agree on compensation that would restore the lost harmony to all concerned. ${ }^{227}$ In addition, the horizontal model of dispute resolution shares the same principles related to the healing of parties. ${ }^{228}$ The traditional indigenous and restorative justice movement trends deal with very concrete processes to settle disputes, especially adult criminal and juvenile wrongdoing cases. ${ }^{229}$

Some tribes use traditional dispute resolution in both civil and criminal cases, while others prefer to apply traditional mechanisms of dispute resolution only in civil cases. ${ }^{230}$ For example, the Hopi, a Native American tribe located in Arizona, have traditional dispute resolution justice in civil cases; however, unlike some other tribes, the Hopi court also has jurisdiction on some more serious crimes. ${ }^{231}$

The Hopi tribe has about 15,000 enrolled members, most of whom live in villages. ${ }^{232}$ Each village elects its governor, who has exclusive authority to decide civil cases such as land disputes, divorces, child custody issues, and so on. ${ }^{233}$ Parties can elect to handle their cases in formal Hopi courts; however, the governor must waive his right to hear the case. ${ }^{234}$ In most cases, the governor agrees to refer the case to the

225. Id. at 58-59.

226. Holly, supra note 222, at 17.

227. Id. at $17-18$.

228. Id. at 18 .

229. James W. Zion, Justice as Phoenix: Traditional Indigenous Law, Restorative Justice, and the Collapse of the State, in NATIVE AMERICANS AND THE CRIMINAL Justice System 51, 51 (Jeffrey Ian Ross \& Larry Gould, eds., 2006).

230. Interview with Carleen Tena Khongva, Public Defender in Hopi Legal Services (DNA), in Hopi Nation, Ariz. (May 24, 2013).

231. Id.

232. Id

233. Id.

234. Id. 
formal court if the parties both consent, but he rarely refers land dispute cases to the formal courts. ${ }^{235}$

These examples of harmony and balance between formal and informal justice practices in Native American tribes could be instructive to countries like Afghanistan in which tribal groups have long traditions of informal dispute resolution. ${ }^{236}$ Indeed, Afghanistan's tribal approaches to informal justice dispute resolution share many values and attributes with these native American systems, including cost-effectiveness, time efficiency, and reasonable resource allocation; however, unlike Native American peacemaking systems, the Afghan informal system has been known to violate state law and human rights. ${ }^{237}$ Nevertheless, as this paper explores below, looking to the Native American examples may not only help Afghanistan find a better balance between the informal and formal systems, but it may also provide a way to eliminate these human rights abuses in the informal system.

\section{b. Peacemaking \& Peacemakers}

Navajo Peacemaking is a form of restorative justice that handles disputes to recover relations between individuals in conflict. ${ }^{238}$ It is one of the most contemporary restorative justice programs in the world. ${ }^{239}$

The [potential] of restorative justice [models] to deal effectively with the consequences of 'crime' [effectively] seems to be much greater because, if we want people who perpetuate violence to live peaceable in society, then it is sensible to develop justice models in which the community is involved in holding him or her accountable. ${ }^{240}$

235. Id.

236. See generally Navajo Nation Peacemaking (Marianne O Nielsen \& James W. Zion eds., 2005).

237. COBURN \& DEMPSEY, supra note 1 , at 3-4.

238. See generally NAVAJo NATION PeACEMAKING, supra note 236.

239. Id.

240. Andrea Smith, Decolonizing Anti-Rape Law and Strategizing Accountability in Native American Communities, 34 Soc. Just. 36, 39 (2012). 
The peacemaking program is a "horizontal system of justice"; this means that parties are treated equally with the aim of preserving ongoing relationships and returning harmony to the parties to the conflict. ${ }^{241}$

The system is considered to be a significant alternative to tribal courts on reservations. ${ }^{242}$ Although the first Peacemaker Courts were established in 1982, they were quickly institutionalized into a Peacemaking Court system in $1991 .{ }^{243}$ The Navajo Nation judges created some rules for Peacemaker Courts to resolve disputes through informal mechanisms without the formal adversarial procedures used by the Navajo Tribal Court. ${ }^{244}$ In the 2000s, the Peacemaking Court's name was changed into "Peacemaking" and Chief Justice Claudeen Bates-Arthur substituted the peacemaking rules into guidelines. ${ }^{245}$ Later the Council approved the Fundamental Law of Dine, and established a peacemaking division, later the "Peacemaking Program", to educate people and develop hozhoji naat aah (may I walk in peace) throughout the Navajo reservation. ${ }^{246}$ Hence, the Navajo peacemaking program not only solves civil and criminal cases, but also educates members of tribes to solve the disputes themselves and to prevent possible future conflicts. ${ }^{247}$

Similar to other restorative justice programs, the Navajo peacemaking courts are held outside of the formal justice halls. ${ }^{248}$ The peacemaking process, rather than relying on the services of formal judges, lawyers, and legal supporters, rely on peacemakers who are known for their fairness, wisdom, respect, and planning ability by community people as decision-making authorities. ${ }^{249}$ Like other Native Nation restorative programs, peacemaking is an accessible, affordable, and informal way of resolving conflict and achieving justice for Native American communities and families. ${ }^{250}$

241. See generally NAVAjo NATION PeACEMAKING, supra note 236.

242. See id. at 110.

243. Id. at 108 .

244. Eric K. Gross, Evaluation/Assessment of Navajo Peacemaking 5 (1999).

245. PEACEMAKING, supra note 203, at 2.

246. Id.

247. See id. at 9 .

248. GROSS, supra note 244, at 5 .

249. PEACEMAKING, supra note 203, at 48.

250. GROSS, supra note 244 , at 5. 
Navajo Peacemaking endeavors to repair the relationship of both sides of the dispute instead of focusing on retaliation. ${ }^{251}$ Thus, it does not label the defendant as the "offender" and the other side as the "victim."252 Each side of the dispute could possess qualities of victimization. ${ }^{253}$ "Moreover, the actualization of violence perpetrated by one person on another will ultimately be understood as the absence of love and nurturance for that person." 254 Peacemaking sessions are held to repair damaged feelings of both sides of the dispute; therefore, the process continues until feelings of parties are satisfied. ${ }^{255}$ Peacemaker, Elaine Henderson, says that Peacemakers solve conflicts between parties by giving them advice, healing their hearts, and making them aware of possible results of cases. ${ }^{256}$ A Peacemaker concentrates on the relationships between people. ${ }^{257}$ She believes "clanship" relates person to person and strengthens relationships. ${ }^{258}$ According to clanship, someone is your brother, uncle, or father; so, a father and uncle have the responsibility to look after you and prohibit you from bad behavior. ${ }^{259}$ Everyone has to respect others and take part in problem solving. ${ }^{260}$ Ultimately, Ms. Henderson also explains that her role is to remove the misunderstanding and miscommunication among people in the community. ${ }^{261}$ She teaches culture, tradition, clanship, and discipline to make parties aware of their culture, tradition, and past relation that make them aware of whatever they may have forgotten from their past. ${ }^{262}$

Although cases between neighbors and relatives constitute a large number of peacemaking cases, quite a few cases are also criminal such as: burning down of people's homes, threats to murder, and occasional assault and battery cases. ${ }^{263}$

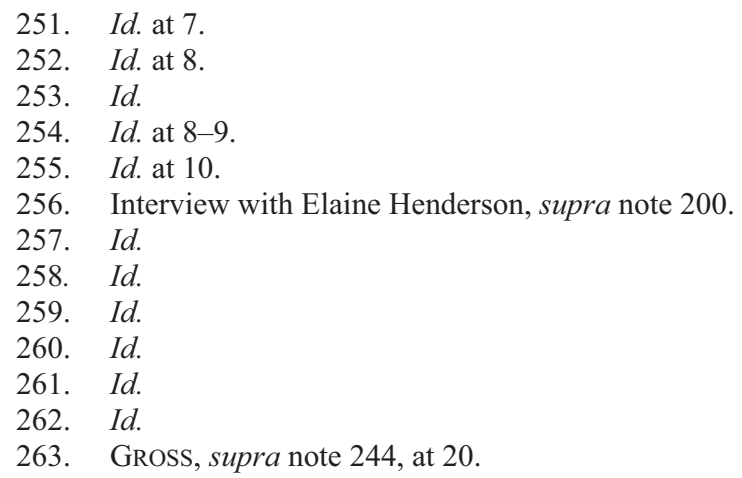




\section{i. Peacemaking in Criminal Cases}

With the evolution of tribal government, criminal law and procedure has changed. ${ }^{264}$ Even though the U.S. federal government gave authority to the Navajo and other Indian tribes to run their own courts approximately a century ago, the Navajo Nation maintains traditional values of dispute resolution to a greater extent than other tribal courts in many other American Indian communities. ${ }^{265}$ Many Native American courts have different programs in their prosecutor's office that include community justice and formal dispute resolution. ${ }^{266}$ Peacemaking is one good way to recommend appropriate disciplinary actions to the criminal or defendant and to address victims' rights. ${ }^{267}$ Parties to the conflict; victims and its relatives; and defendant and its relatives, settle and agree on the terms of sentence and ask a Peacemaker to deliver it for them. ${ }^{268}$

In addition, Peacemakers can influence decisions not by imposing them or taking sides; instead they present ideas and suggestions on how parties can discuss and resolve their disputes. ${ }^{269}$ Thus, Peacemaking is a pivotal settlement of dispute approach for Native American communities since it includes their involvement in the dispute resolution process and responds to their needs. ${ }^{270}$ In addition, it is a good rehabilitative process for the offenders because in Navajo restorative justice the burden is on all components of the justice system to work for the offender's rehabilitation and bring him or her back to the community in a peaceful way. ${ }^{271}$ In addition, this system does not label individuals as the offender, or wrongdoer, and the victim. ${ }^{272}$ Instead, it encourage parties to "Hozhoogo naashaadoo (may I walk-in peace) and Hozhoojii saad bee atchI yadeilti doo (may we communicate in peace)." ${ }^{273}$ The Peacemaking

\footnotetext{
264. GARROW \& DEER, supra note 218, at 53.

265. Holly, supra note 222, at 17.

266. See generally GARROW \& DEER, supra note 218.

267. See generally Holly, supra note 222.

268. Interview with Elaine Henderson, supra note 200.

269. See GARROW \& DEER, supra note 218, at 57-58.

270. Id.

271. PEACEMAKING, supra note 203, at 29.

272. Id. at 12 .

273. Id.
} 
Program teaches the offender and victim their responsibilities, how to be a good person, and how to prevent criminal offenses. ${ }^{274}$

\section{ii. Peacemaking in Civil Cases}

Navajo Nation Peacemakers solve a large number of civil cases through healing, talking, looking for alternatives, and guidance to the involved parties. ${ }^{275}$ For instance, in a divorce case, peacemakers "may engage in talking with the person or persons in order to see if alternatives to a divorce are possible, and the family preserved." ${ }^{276}$ For this purpose, the peacemaker makes the parties (husband and wife) aware of upcoming results of the divorce that could cause social and mental problems of their children. ${ }^{277}$ The Peacemaker says to the parties, do not think about yourself, think about your children and their future. ${ }^{278}$ What will happen if you divorce? Parties to conflict mostly accept the Peacemaker's advice. $^{279}$

\section{ANALYSIS: LESSONS FOR AFGHANISTAN FROM THE NAVAJO NATION}

It is both necessary and critical that the Afghan criminal justice system strengthens its ability to resolve criminal disputes all over the country. ${ }^{280}$ In urban areas, the formal criminal justice system governs all criminal disputes and these Afghans can access the formal justice system. ${ }^{281}$ However, the formal criminal justice institutions, including criminal courts, do not function in some rural areas and lack the capacity to effectively administer justice. ${ }^{282}$ As shown in earlier sections of this paper, this lack of capacity and effectiveness of formal legal institutions in rural areas has several causes such as: 1) since 2001, the Afghan government and international forces have failed to maintain and stabilize security in the most rural areas; 2) the strong influence and dominance of

\footnotetext{
274. Interview with Elaine Henderson, supra note 200.

275. See Peacemaking, supra note 203, at 13.

276. Id. at 17.

277. Interview with Elaine Henderson, supra note 200.

278. Id.

279. Id.

280. DEMPSEY \& COBURN, supra note 4, at 2.

281. Id.

282. BARFIELD ET AL., supra note 2, at 2.
} 
warlords exacerbate the problem in rural areas because they misuse their power and influence; 3 ) the presence of widespread corruption especially in the district courts. ${ }^{283}$ Therefore, it is better to focus on strengthening and reforming existing traditional institutions and linking them to state institutions rather than trying to marginalize them.

In the short term, cooperation between the informal dispute settlement mechanisms and the formal legal institutions will produce a much better system that can resolve community disputes. For instance, the involvement of the formal system would reduce the freedom of jirgas and shuras in dispute settlement by subjecting them to a series of rules and regulations. Regardless, the informal system would still be accessible to tribal and community members possibly throughout the country.

While the absence of trust in the formal institution, due to widespread corruption, has created a sense of dissatisfaction and the feeling that the legal institutions are unfair, once the two systems are linked, the local peoples' trust will increase in the system because of the integration of their own leaders into the formal system, who they can trust. Accordingly, the creation of a mechanism that links the formal courts and institutions with the informal one is necessary and can function quite efficiently. This will function similar to the Peacemaking Program in the Navajo Nation, where the minor criminal disputes are settled by the informal entities and the outcome is registered and recorded in the formal courts records. ${ }^{284}$

In addition, the Afghan informal justice system is praised for its promptness, clarity, cultural familiarity, trustworthy outcomes, prompt resolutions, lower costs, accessibility, unanimous enforceable decisions, fairness, and focus on restorative justice and preserving harmony within the community; ${ }^{285}$ however, it has been condemned for violation of human rights, especially women's rights, Islamic principles, and state law. ${ }^{286}$ For example, as explained above, shuras and jirgas treat women quite discriminatorily and harsh in cases involving marriage and divorce issues. ${ }^{287}$ They also do not pay due regard to Islamic and state law and

283. See generally id.

284. Interview with Elaine Henderson, supra note 200.

285. DEMPSEY \& COBURN, supra note 4 , at 3.

286. Id. at 2-3.

287. UNAMA, supra note 92, at 48. 
principles because they mostly rely on traditional custom to resolve major criminal cases, including cases that involve murders, rapes, housefleeing, and theft. ${ }^{288}$ Thus, in the long term, it is better to limit the authority of the informal justice system to less serious crimes and to restrict decisions for more serious criminal cases to the formal courts.

\section{a. Barriers to Implementing this New Approach}

Both formal and informal justice systems in Afghanistan are confronted with some barriers; these barriers do not let the systems solve civil and criminal matters appropriately and effectively. ${ }^{289}$ Some of these barriers are as follows.

\section{i. $\quad$ Security}

The justice system of Afghanistan, like elsewhere, is closely related to security. ${ }^{290}$ Lack of security is one big barrier toward access to justice and stabilizing the rule of law. ${ }^{291}$ Thus, it is difficult to implement state laws and regulations in some rural areas of Afghanistan. ${ }^{292}$ It can also be a barrier to implementing some of the broad and unfocused traditional dispute resolutions such as jirgas and shuras because the insurgents only believe in their own justice system to ensure their own interests. ${ }^{293}$ Unfortunately, that justice system is neither in accordance with the state law of Afghanistan nor Islamic Law and the cultural values of the people. ${ }^{294}$ However, one possible solution could be to start the reform from the secure places and expand it to other areas gradually. That reform includes involving more local actors that deliver justice and maintain the rule of law through informal dispute resolution. That way, justice will be delivered and the rule of law will be maintained while also strengthening the security situations and bringing stability by promoting

288. JOHNSON ET AL., supra note 92, at 27; see generally UNAMA, supra note 92.

289. DEMPSEY \& COBURN, supra note 4 , at 3.

290. Id. at 1.

291. Id. at $1-2$.

292. Id.

293. BARFIELD ET AL., supra note 2, at 13-14; see generally UNITED STATES INSTITUTE OF PEACE, supra note 9.

294. See generally COBURN, supra note 128. 
local actors and elders who are valued and are perceived to be deserved decision-makers in the area.

\section{ii. Lack of Rule of Law}

The contemporary formal justice system of Afghanistan, including formal courts, is often seen to be, corrupt, expensive, inaccessible, and not trustworthy to the rural people. ${ }^{295}$ In addition, some judges, prosecutors, and police officers are not well trained and sometimes they themselves violate state laws. ${ }^{296}$ Hence, the formal justice institutions are less capable to settle serious crimes and monitor the informal justice system when dealing with less serious crimes. However, strengthening the rule of law may be achieved through maintaining security by empowering the Afghan police and National Army.

It is unrealistic to believe that informal justice systems are immune from warlords, corruption, nepotism, and other factors influencing the procedural fairness. A big barrier is the interference of local commanders, warlords, and powerful government officials in the decision-making processes within the system of informal legal practices. ${ }^{297}$ Another barrier is the lack of legal knowledge among community leaders or elders. ${ }^{298}$ Most of the jirgas and shuras members are local elders who only have basic legal knowledge or none at all regarding the laws and regulations of Afghanistan. ${ }^{299}$ Thus, while making decisions, they possibly violate state laws and human right principles. ${ }^{300}$

b. Suggestions for a New Approach to Working with the Informal Justice System

In order to improve the informal justice system in the rural areas of Afghanistan and avoid the corrosive aspects of informal dispute resolution, I propose the following recommendations:

295. DEMPSEY \& COBURN, supra note 4, at 3.

296. Interview with Jamshid Sabori, Police Officer, in Kabul, Afg. (Spring 2013).

297. BARFIELD ET AL, supra note 2, at 3,14-15, 21.

298. See COBURN, supra note 128 , at 47.

299. See DEMPSEY \& COBURN, supra note 4, at 2; see also BARFIELD ET AL., supra note 2 , at 2 .

300. See BARFIELD ET AL., supra note 2, at 3. 


\section{i. Collaboration of Formal Courts and Law Enforcement Institutions with the Informal Justice System}

The Native American justice system, especially the Navajo Nation justice system, could be a good model for the Afghan government to follow, because in the Navajo Nation, there is not only collaboration of courts with the peacemaking program, but also with other government institutions in order to achieve its goals. ${ }^{301}$ Similarly, the Afghan courts and law enforcement institutions could help community-based resolution bodies to solve most criminal and civil cases in peaceful ways that could fulfill the needs of both parties to the conflict.

\section{ii. Appropriate Dispute Resolution}

Like the Native American peacemaking program, the Afghan informal justice system should focus on healing hearts, finding appropriate alternatives, and peaceful resolution of disputes. As mentioned above, Native American tribal peacemaking programs solve criminal disputes in ways that satisfy the needs of the parties to the conflict and do not contradict reservation law or state law. ${ }^{302}$

\section{iii. Who Should Decide What?}

The Afghan informal justice system should settle only minor criminal cases. Cases involving murder, theft, rape, honor killing, and so on, should be handed by formal legal institutions. Like the Native American tribes, if these cases are brought to informal dispute bodies, they should be removed to the formal courts through a mutually respectful process fostered by a cooperative relationship and communication between the formal and informal systems. As a part of this cooperative relationship, province governors and district governors should be given authority to observe informal dispute resolution in less serious criminal cases, and the convention of jirga and shura should be called upon to settle large dispute between tribes.

301. See generally PEACEMAKING, supra note 203.

302. JUdiCIAL BRANCH OF THE NAVAJO NATION, supra note 16. 
The Navajo peacemaking programs educate the community members on how they should settle their disputes and inform them of their social responsibilities. ${ }^{303}$ This program has been very effective in the Navajo Nations, and the Afghan informal justice system could benefit from the same kind of programming. This programming could be led by local elders, law school students, and maybe even district governors who could educate the community members and inform them on the functions of the formal and informal justice systems and the ways in which they can resolve their disputes peacefully and effectively.

\section{v. Communication, Monitoring, and Removal}

The formal and informal justice systems can be integrated either through establishing formal institutions to take over and manage informal justice mechanisms. In this approach, informal justice mechanisms would refer cases to formally established institutions for settlement. The formal institutions would advise the informal institutions in settling that particular dispute. Then the informal institutions would issue the decision to the parties. This could be a mutual dispute settlement mechanism. However, this approach seems quite challenging to achieve, for two reasons. First, if formal institutions take over informal justice mechanisms, it is likely that formal institutions will face resistance from the local communities and tribes as they do not believe in the formal institutions' effectiveness. The second, and perhaps the more important, reason is that local communities and tribes are not willing to let the traditional way of settling disputes, which they have known since they first resolved a dispute, go easily.

A more realistic approach that can integrate the formal and informal justice systems in Afghanistan could be that both mechanisms should build a partnership in which informal institutions refers most serious criminal cases, such as murder, rape, and serious domestic violence to the formal institutions for settlement. Formal institutions in turn would refer less serious criminal cases, such as minor theft, less serious injuries, minor domestic violence, and obscenity to the informal system for

303. See generally PEACEMAKING, supra note 203. 
settlement. This approach has multiple advantages. First, the formal institutions will help enforce decisions of the informal institutions when the parties refuse to agree. Second, the referral of the most serious criminal cases to the formal system will preserve the legal rights of the parties to the case.

Once the formal and informal justice systems are linked and the community is informed of both the formal and informal disputes settlement methods, the system should be monitored by state officials. Active monitoring by the formal law enforcement institutions and the creation of regular mechanisms that build links between the state and traditional systems could help hold the informal peacemakers within their limits and encourage adherence to and compliance with the formal system's laws. It can further help the formal recording and storage process for traditional justice decisions, registering decisions with the state, the designation of a respected individual as a liaison between the state, community, shuras and jirgas.

As many members of the informal justice mechanisms, such as Shuras and Jirgas, do not have any kind of legal training, they face some challenges in settling disputes. ${ }^{304}$ Sometimes the rights of one party are completely ignored because the other party is a prominent figure in a society or tribe. ${ }^{305}$ Here, I suggest that the formal institutions should monitor the informal institutions in preventing them from ignoring one party's rights and accordingly direct them to act impartially. This can take place by training the informal dispute resolvers. Furthermore, as in many rural districts in Afghanistan, district governors directly act as members of dispute settlement institutions. I suggest that they should monitor the process too. For example, they can act as the state representative besides being a member of the informal disputes settlement body. In this capacity, they can avoid any violence in the process; and they can encourage the members of the jirgas and shuras to take the interests of all parties into consideration.

304. See generally COBURN, supra note 128.

305. See generally COBURN \& DEMPSEY, supra note 1. 
X. CONCLUSION

In most parts of rural areas jirgas and shuras play an essential role in the resolution of civil and criminal disputes. ${ }^{306}$ In spite of having deep roots at the tradition and culture, they create problems for the formal state justice institutions, especially when they violate human rights, Islamic principles, and state law. ${ }^{307}$ Nonetheless, people in rural areas consider jirgas and shuras as legitimate and authoritative bodies of dispute resolution. ${ }^{308}$ Informal justice institutions could be considered as an important factor of stabilizing the rule of law and improving access to justice, if they function according Islamic principles, human right principles, and state laws. Hence, to make the Afghan informal justice system sufficient and effective, they should be reformed and monitored through formal institutions and law enforcement entities. To reduce the negative effects of informal dispute resolution, the Afghan informal justice system should follow the Native American informal dispute resolution and peacemaking model, especially the Navajo Nations, in less serious crimes and submit serious crime cases to the formal courts.

Afghan informal dispute resolution systems are common in the most rural areas of Afghanistan, and they have been praised for their promptness, clarity, low cost, effectiveness, and familiarity to the local people. ${ }^{309}$ However, they have also caused concern because they have been known to violate state laws, Islamic principles, and human rights. The most pressing of these concerns is related to human rights. ${ }^{310}$ Thus, to ensure rule of law, and protect principles of human rights, and Islamic law within informal systems, it will be necessary to develop a cooperative system of communication, monitoring, and removal of serious cases to formal courts.

This paper argues that if Afghanistan learns from the Navajo Nation's Peacemaking system, it will promote a much better dispute resolution mechanism, incorporating cooperation and monitoring and implementing an appropriate and respectful system of removal of serious cases, which

306. DEMPSEY \& COBURN, supra note 4, at 2.

307. BARFIELD ET AL., supra note 2, at 3.

308. COBURN \& DEMPSEY, supra note 1 , at 2-3.

309. DEMPSEY \& COBURN, supra note 4 , at 3.

310. See BARfIELD ET AL., supra note 2, at 3; see also CoBURn \& DEMPSEY, supra note 1 , at 6 . 
will link the formal and informal justice systems to promote peace and justice in all regions of Afghanistan. 